\title{
COMMENTARY
}

\section{RECENT ASEAN DEVELOPMENTS ON PEATFIRES AND HAZE: NATIONAL RESPONSES}

\author{
Helena Varkkey
}

\begin{abstract}
The recent haze episodes of 2013 and 2015 have been especially severe. With satellite imagery and news reports pinpointing sustained peatfires as a major source of the haze, national and regional responses have focused on peatlands. At the ASEAN level, ongoing efforts to address peat and haze issues focus around two documents, namely the ASEAN Agreement on Transboundary Haze Pollution (ATHP) 2002 and the ASEAN Peatland Management Strategy (APMS) 2006-2020. This paper analyses the latest national responses within the context of these documents. Singapore's Transboundary Haze Pollution Bill ties in closely to the ATHP's Haze Monitoring System (HMS) as it needs accurate land maps so that Singaporean prosecutors can correctly assign blame. The HMS is however constrained as concession maps are available on a case-by-case basis only. Indonesia has finally ratified the ATHP and this has renewed regional interest in the establishment of the ASEAN Coordinating Centre for Haze in Riau, which, due to its location close to some of the most severe peatfires, is hoped to encourage more local ownership of the issue. However, Indonesia has announced that it needs at least another three years before a marked reduction of haze episodes.
\end{abstract}

Keywords: ASEAN, transboundary haze, peatland management, fire monitoring, Haze Monitoring System

\section{INTRODUCTION}

The recent transboundary haze episodes of 2013 and 2015 have been especially severe, with serious consequences on the day-to-day lives of Indonesians living closest to the fires and in neighbouring countries, especially Malaysia and Singapore. Singapore experienced it worst haze ever on record in June 2013, with its Pollution Standards Index (PSI) reaching 401, ranked as extremely hazardous. In September 
2015, an emergency was declared in Riau, Sumatra, the worst-hit Indonesian province that was close to the epicentre of the fires. And during the same period in Malaysia, schools were closed in three states and the federal territories for several days as air quality worsened.

Satellite imagery captured during these two haze episodes detected hundreds of hotspots in Kalimantan, Sumatra, and to a lesser extent Peninsular Malaysia and Sarawak. The majority of these hotspots were on peatland areas, and plumes of smoke rising out of these areas were clearly visible. ${ }^{1}$ Peatfires are notoriously hard to put out, as these fires often spread over vast distances underground. These smouldering fires emit thick, sooty smoke that is heavy enough to travel far distances in the atmosphere. One study has indicated that about $80 \%$ of the regional haze consists of smoke from peatfires. ${ }^{2}$ With satellite imagery and news reports pinpointing sustained peatfires as a major source of the haze, national and regional responses have, more than ever, focused on peatlands. Hence, the purpose of this paper thus is to analyse the latest national responses within the context of regional peat and haze initiatives.

At the ASEAN level, ongoing efforts to address peat and haze issues focus around two documents, namely the ASEAN Agreement on Transboundary Haze Pollution (ATHP) 2002 and the ASEAN Peatland Management Strategy (APMS) 2006-2020. This commentary analyses the latest national responses within the context of these documents, particularly on the 2013 Haze Monitoring System (HMS) and the soon-to-be-established ASEAN Coordinating Centre for Haze $(\mathrm{ACCH})$. Two responses are of particular interest, namely Singapore's Transboundary Haze Pollution Bill (THPB) 2014, and Indonesia's recent ratification of the ATHP.

\section{REGIONAL INITIATIVES}

The ATHP, which was adopted by all ASEAN member countries in 2002 and brought into force in 2003, was meant to provide legally binding support to an earlier ASEAN document, the Regional Haze Action Plan. ${ }^{3}$ Hence, the ATHP is notable for being one of the few legally binding ASEAN environmental agreements to be entered into force. ${ }^{4}$ The Agreement's stated objective, under Article 2, is “to prevent 
and monitor transboundary haze pollution as a result of land and/or forest fires which should be mitigated, through concerted national efforts and intensified regional and international cooperation". 5

However, up till late 2014, the ATHP remained ratified by only nine ASEAN states, with the Philippines being the ninth country to ratify in early 2010. Indonesia held off ratification till 16 September 2014. During this time, the effectiveness of the ATHP was severely crippled, in the following ways:

1. ASEAN-level initiatives have not been able to address sensitive issues like influencing Indonesian land and forest policy and the implementation of laws ${ }^{6}$

2. Neighbouring countries offering assistance still have to await diplomatic clearance ${ }^{7}$

3. Delayed establishment of the ACCH and its dedicated Secretariat. ${ }^{8}$

The APMS was also designed to provide support to an earlier ASEAN project, the ASEAN Peatland Management Initiative 2002. ${ }^{9}$ It was developed to provide a common framework for peatland management in the region in the period 2006-2020. There are four main objectives to the strategy, namely: ${ }^{10}$

1. To enhance understanding and build capacity on peatland management issues in the region

2. To reduce the incidence of peatland fires and associated haze

3. To support national and local level implementation activities on peatland management and fire prevention

4. To develop a regional strategy and cooperation mechanisms to promote sustainable peatland management

As part of the APMS, ASEAN Member Countries with significant peatlands are to develop complementary National Action Plans (NAPs) on Peatlands. The NAPs are to provide the respective countries with their national focus, and identify agencies involved, funds and requirements for implementing activities towards the sustainable management of peatlands. ${ }^{11}$ Currently, two projects 
are being implemented to support the implementation of regional and national strategies for sustainable management of peatlands in Southeast Asia and the incorporation of peatland management into policies and plans related to forest and land-related resources. These two complementing projects are the Rehabilitation and Sustainable Use of Peatland Forests in Southeast Asia (APFP Project) and the Sustainable Management of Peatland Forest in Southeast Asia (SEApeat Project) (www.peat-portal.net). ${ }^{12}$

\section{NATIONAL RESPONSES}

\section{Indonesia}

The guidelines provided by the APMS proved useful to Indonesia when it was able to submit its Nationally Appropriate Mitigation Action (NAMA) plan on Sustainable Peatland Management to the United National Framework Convention on Climate Change (UNFCCC) in January 2010. ${ }^{13}$ Thanks in part to this effort, Indonesia has managed to secure substantial international funding for national peatland management efforts, namely from the Global Environment Facility (GEF) Trust Fund ${ }^{14}$ and from the Ministry of Environment, Japan in collaboration with the Global Environmental Centre (GEC). A feasibility study carried out after one year of the Japan-GEC collaborative project showed positive results, with a projection of $227,500 \mathrm{t}-\mathrm{CO} 2 / \mathrm{yr}$ GHG reduction estimation at the 10,000 hectare project site area. ${ }^{15}$

In terms of the ATHP, it was mentioned above that Indonesia delayed ratification of the ATHP for over a decade. Finally in September 2014, the outgoing President Susilo Bambang Yudhoyono announced Indonesia's ratification of the instrument as one of his final acts in office. Indonesia's ratification of this treaty was received with much fanfare by the other ASEAN countries, and marked renewed goodwill over collective action to mitigate haze.

In terms of peatland management in particular, it was hoped that the ratification of the ATHP would mean that there could be more candid and open discussion and consultation at the ASEAN level over the previously deemed 'too sensitive' issues of 
land policy, peatland in particular. However, ratification does not mean that the earlier three limitations mentioned in the previous section will automatically be resolved. Out of the three points, the one with the most positive outlook is the final one, on the ACCH. Hope for the first two, including that pertaining to peatland policy, may be overstated. This is because, in the nature of other ASEAN agreements, the ATHP was also vague and lacking in various hardlaw instruments such as strong dispute-resolution or enforcement mechanisms ${ }^{16}$, or any provisions for dispute settlements through international courts or other arbitration tribunals. ${ }^{17}$ This means that Indonesia still cannot be called to task if they should refuse to cooperate on these two points, despite ratification. Indeed, none of the ASEAN countries did so during the recent 2015 haze episode.

However, there is much hope for the third point on the ACCH. Currently, the ASEAN Secretariat in Jakarta, which acts as an interim coordination centre, is crippled by its limited staff and location far away from the fires. Shortly after Indonesia's ratification, ASEAN Environmental Ministers renewed discussions for the establishment of the ACCH in Riau. ${ }^{18}$ The centre's new location in Riau is hoped to fuel more awareness and ownership of the fire problem in the Riau administration, in addition to coordinating information and cooperation efforts around the region. ${ }^{19}$ This dedicated $\mathrm{ACCH}$ in Riau should be better able to: ${ }^{20}$

1. Establish and maintain regular contact with the respective National Monitoring Centres regarding haze data;

2. Facilitate co-operation and co-ordination among the Parties to increase their preparedness to respond to fires and haze;

3. Facilitate co-ordination among the Parties, other States and relevant organizations to mitigate the impact of fires and haze; and

4. Transmitting promptly the request for assistance to other States and organizations; and co-ordinating such assistance.

Presently however, the ACCH continues to be in the discussion stage and has yet to be formally established in Riau. 


\section{Singapore}

Singapore on the other hand had a quite different set of responses to the ASEAN initiatives as compared to Indonesia. Singapore proposed to ASEAN the establishment of a HMS in 2013 to further operationalize the ATHP, especially in terms of the implementation of land and forest policies and laws. The HMS was conceptualised as a platform for openaccess digitized land-use maps and concession maps of fire-prone areas that cause haze, to act as a deterrent to errant companies. ${ }^{21}$ Affected parties may also bring civil suits against errant entities..$^{22}$ The Bill is unique for its application of extra-territoriality; it covers the operations of all Singapore and non-Singapore entities whose activities outside of Singapore contribute to haze pollution in the city-state. Since proving what happens abroad is difficult, evidential presumptions relating to causation (linking open burning elsewhere and wind direction with the presence of haze in Singapore) and culpability (based on ownership and occupation of land) help to give teeth to this Bill.

This was meant to complement another Singaporean initiative that was put into force the following year, which was the THPB, which provides for criminal and civil liability for any Singaporean or non-Singaporean entity causing or contributing to transboundary haze pollution in Singapore. ${ }^{23}$ The THPB makes it a criminal offence when an entity engages in conduct, or authorizes any conduct which causes or contributes to haze in Singapore. The Bill is unique for its application of extra-territoriality; it covers the operations of all Singapore and non-Singapore entities whose activities outside of Singapore contribute to haze pollution in the city-state.

Even though ASEAN formally adopted Singapore's HMS idea at the 14th Sub-Regional Ministerial Steering Committee on $\mathrm{Haze}^{24}$, this was not without significant watering-down, as is the fate of many ASEAN agreements. Indonesia (and Malaysia as well) cited privacy and legal concerns of making maps publicly accessible. Indonesia also argued that its own One Map Initiative was underway, so there was no need for this additional platform which would essentially serve the same purpose. With these reservations, ASEAN adopted the HMS with maps to be shared on an ad-hoc, governmentto-government basis only, much to Singapore's disappointment. 
Singapore, as well as other ASEAN observers, expressed concern that this lack of transparency severely damaged the credibility of this system, and other actors not privy to the maps will continue to view the HMS, and by extension the governments with suspicion. And while it is exemplary that Indonesia is taking unilateral effort with the One Map Initiative, problems related to its decentralization process $^{25}$, where local governments can now apply to change forest classification areas every five years, has meant that forest classifications are changing at a much more rapid rate, often faster than maps can be updated. This has drastically slowed down the One Map Initiative.

The THPB importantly allows for reliance on satellite imagery, meteorological information, and maps as evidence. ${ }^{26}$ This was why Singapore placed high hopes on the HMS to provide accurate land maps, so that Singaporean prosecutors can correctly assign blame. Furthermore, such maps can also be used by companies to defend itself by proving the fires were caused by natural disaster or by parties not under its direction. However, the watering down of the HMS and the repeated delay of Indonesia's One Map Initiative makes identifying errant companies problematic. Because of this, Singapore's National Environment Agency (NEA) would need to work closely with their counterparts in Indonesia to build a case against these companies. ${ }^{27}$ However, Indonesia has thus far shown a weak track record; clearing land through burning is prohibited in Indonesia but authorities have so far only successfully prosecuted a handful of companies for starting such fires. Hence, the effectiveness of the THPB as a plausible tool to mitigate peatfires and haze remains to be seen.

Following the haze episode in 2015, Singapore's NEA requested information from the Indonesian government to provide details of companies it suspects of causing haze pollution. Following this, the NEA has sent Preventive Measure Notices to four Indonesian companies pursuant to Section 9 of the THPB, requesting them to: ${ }^{28}$

1. Deploy fire-fighting personnel to extinguish or prevent the spread of any fire on land owned or occupied by them; 
2. Discontinue, or not commence, any burning activities on such land;

3. Submit to NEA any plan of action to extinguish any fire on such land or to prevent its recurrence.

The information provided by these companies were hoped to assist the NEA in its investigations under the THPB. However, it is obvious that the effectiveness of the Bill is reliant on the cooperation of the alleged perpetrator, as a result from the watering down of the HMS mechanism.

Indeed, so far the response to this Bill has not been positive. Not only has the perpetrators largely refused to provide information to Singapore, Indonesia itself has protested Singapore's actions, while insisting that the ATHP should have precedence over haze matters, and not any individual country's laws. It remains to be seen if Singapore will take a hard stance in response to Indonesia's protests. Hence, while the THPB is novel and promising, various limitations within the ASEAN framework is a serious stumbling block.

\section{CONCLUSION}

In 2014, the author attended a NGO Roundtable on Environment, Sustainability and Climate Change, where discussants pointed out that a common weakness in a lot of the ASEAN initiatives on peatfires and haze is that while many initiatives like the ATHP and HMS is useful to be applied when the fires occur, they were not preventive in nature. The discussants noted that it was important for the haze to be framed as not merely a fire problem, but more broadly as a land use issue, and specifically as a peatland management issue. When peatland disturbances occur, fires, whether accidental or intentional, will become more likely.

While initiatives like the APMS can be considered more preventive, usually these types of initiatives are not given as much attention or importance, either from the government or even the media, as compared to the more reactive ones as discussed above. 
A good example is the fanfare involved around Indonesia's longawaited ratification of the ATHP, while the peatland management projects ongoing under the APMS remain relatively unknown in ASEAN circles. Furthermore, for such preventive measures, participating countries often rely on external assistance as seen above, and are often not proactively involved in the preventive action. This becomes a problem when fire and haze events actually do occur, where governments are suddenly thrust into action in unfamiliar (peat)soil.

Indonesia has announced that it needs at least another three years before a marked reduction of haze episodes. Indonesia's three-year timeline does still fall within the timeframe of the APMS, which ends in 2020. Herein lies an opportunity for Indonesia, under the fresh leadership of Joko Widodo, to change the country's hitherto reactive approach to peatfire and haze management to a more preventive approach, as outlined in the APMS. The APMS should be a useful tool to inform developments of Indonesia's fire and peatland management policy in the years to come, not only for Indonesia, but for the region as a whole.

\section{NOTES}

1 National Aeronautics and Space Administration (NASA), "Smoke Blankets Indonesia. Image of the Day," 2015, <http://earthobservatory.nasa. gov/IOTD/view.php?id=86681>

2 C. L. Reddington, M. Yoshioka, R. Balasubramanian, D. Ridley, Y. Y. Toh, S. R. Arnold, and D. V. Spracklen, (2014). "Contribution of vegetation and peat fires to particulate air pollution in Southeast Asia," Environmental Research Letters, Vol. 9, No. 9, 2014, <http://stacks.iop.org/1748-9326/9/ $\mathrm{i}=9 / \mathrm{a}=094006>$

3 E. R. Florano, "Assessment of the "Strengths" of the New ASEAN Agreement on Transboundary Haze Pollution," International Review for Environmental Strategies, Vol. 4, No. 1, 2003, pp. 127-147.

4 ASEAN Secretariat. (2004). 4: Transnational Issues. Paper presented at the ASEAN Annual Report.

5 ASEAN Secretariat. (2002). ASEAN Agreement on Transboundary Haze Pollution Kuala Lumpur. 
6 Ibid.

7 A. Khalik, "ASEAN ups pressure on haze as lawmakers bicker," Jakarta Post, 14 October 2006.

8 ASEAN Secretariat, 2002.

$9 \quad$ N. E. Ramirez, "ASEAN Peatlands Management Strategy 2006-2020: Promoting sustainable management of peatlands in Southeast Asia," ASEAN Biodiversity, January-April 2013, pp. 14-16.

10 ASEANpeat, "Regional Policy Framework. Peatlands in Southeast Asia," Petaling Jaya, Malaysia: ASEAN Peatland Forests Project (ASEANpeat), 2016, <http://www.aseanpeat.net/index.cfm?\&menuid=42>

11 Ibid.

12 Ramirez, “ASEAN Peatlands Management Strategy 2006-2020.”

13 S. Thamrin, "Indonesia's National Mitigation Actions: Paving the Way towards NAMAs," Paper presented at the CCXG/Global Forum on Environment Seminar on MRV and Carbon Markets, Paris. 2011.

14 GEF Trust Fund, "Project Identification Form (PIF), 2014.

15 T. Motoda, "MOEJ/GEC Feasibility Study (FS) Programme for New Mechanisms," Osaka: Global Environment Centre (GEC) Foundation, 2010, $<$ http://www2.gec.jp/gec/jp/Activities/unfcccconf/sb34se/1-GEC.pdf $>$

16 P. Nguitragool, "Negotiating the Haze Treaty," Asian Survey, Vol. 51, No. 2, 2011, pp. 356-378. See also, Transboundary Haze Pollution Bill No. 18/2014, Singapore: Parliament of Singapore, 2014.

17 A. K. Tan, "The ASEAN Agreement on Transboundary Haze Pollution: Prospects for Compliance and Effectiveness in Post-Suharto Indonesia," N.Y.U. Environmental Law Journal, Vol. 13, 2005, pp. 647-722.

18 ASEAN Secretariat, "Declaration on ASEAN Post-2015 Environmental Sustainability and Climate Change Agenda," Kuala Lumpur, 2015.

19 ASEAN Secretariat (2002).

20 Ibid.

21 National Environment Agency, "Factsheet on Transboundary Haze Pollution," Singapore.

22 Parliament of Singapore, 2014.

23 Ibid.

24 National Environment Agency, 2014.

25 K. Austin, et al., Indonesia's Forest Moratorium: Impacts and Next Steps, Working Paper, Washington DC: World Resources Institute (WRI), January 
2014, $<$ https://www.wri.org/sites/default/files/indonesia-forest-moratoriumnext-steps.pdf $>$

26 G. Chua and D. Ee, "Govt. seeks feedback on law on haze," The Straits Times, 21 February 2014.

27 S. Tay and C. W. Chua, "To end the haze problem, both penalties and cooperation are needed," Today Online, 21 February 2014, <http:// www.todayonline.com/singapore/end-haze-problem-both-penalties-andcooperation-are-needed $>$

28 "Singapore send notices to four Indonesian companies and seeks information from Singapore-listed APP," Press Release, Singapore: Ministry of Communications and Information, Singapore, 25 September 2012, <https://www.gov.sg/news/content/singapore-sends-notices-to-fourindonesian-companies-and-seeks-information-from-singapore-listed-app $>$ 